\title{
PENINGKATAN PRESTASI DAN KEMANDIRIAN BELAJAR MAHASISWA MELALUI PENDEKATAN RECIPROCAL TEACHING DAN COOPERATIVE LEARNING
}

\author{
Eli Rohaeti, Suwardi, dan Jaslin Ikhsan \\ FMIPA Universitas Negeri Yogyakarta \\ email: rohaetieli@yahoo.com
}

\begin{abstract}
Abstrak: Penelitian tindakan kelas ini bertujuan untuk mendeskripsikan prestasi dan kemandirian belajar mahasiswa setelah mengikuti kegiatan pembelajaran dengan pendekatan reciprocal teaching dan cooperative learning. Subjek penelitian adalah mahasiswa Program Studi Pendidikan Kimia FMIPA UNY yang menempuh mata kuliah Kimia Fisika II pada tahun akademik 2009/2010. Penelitian tindakan kelas dengan dua siklus ini meliputi langkah-langkah perencanaan, implementasi tindakan, observasi, dan refleksi. Hasil penelitian menunjukkan bahwa setelah mengikuti perkuliahan, terdapat 92,31\% mahasiswa yang mencapai ketuntasan belajar secara individual. Kemandirian belajar mahasiswa juga meningkat. Mahasiswa menunjukkan tanggapan positif terhadap perkuliahan. Mahasiswa antusias mengikuti kuliah.
\end{abstract}

Kata Kunci: cooperative learning, belajar mandiri, kimia fisika, reciprocal teaching

\section{IMPROVING STUDENTS' ACHIEVEMENT AND LEARNING INDEPENDENCE THROUGH RECIPROCAL TEACHING APPROACH AND COOPERATIVE LEARNING}

\begin{abstract}
This action research was aimed at describing the students' achievement and learning independence after joining the instruction using the reciprocal teaching approach and cooperative learning. The subjects were the students of the chemistry education department of FMIPA UNY taking the physics chemistry course II in the 2009/2010 academic year. The steps of this two-cycle action research included: planning, acting, observing, and reflecting. The findings showed that after joining the instruction, $92.31 \%$ of students had reached mastery learning individually. The students' learning independence also improved. The students showed positive evaluation toward the instruction. The students were enthusiastic in joining the course.
\end{abstract}

Keywords: cooperative learning, independent learning, physics chemistry, reciprocal teaching

\section{PENDAHULUAN}

Kimia Fisika II merupakan mata kuliah yang dapat dimanfaatkan sebagai sarana untuk mengembangkan kemampuan mahasiswa berpikir abstrak, berpikir analitis, bernalar dengan baik, dan berkemampuan memecahkan masalah dengan baik pula. Secara operasional, untuk menunjang pencapaian kemampuan-kemampuan tersebut diperlukan adanya sarana pendukung, pemilihan metode, pendekatan pembelajaran yang sesuai, dan penciptaan suasana kondusif yang melibatkan mahasiswa secara aktif dalam kegiatan pembelajaran (Riyanto, 2010).

Berdasarkan pengamatan selama ini, kemampuan yang seharusnya tumbuh melalui aktivitas pembelajaran Kimia Fisika II belum tercapai dengan baik. Mahasiswa masih meng- alami kesulitan memahaminya dengan baik, terutama dalam hal memecahkan soal yang memerlukan penalaran dan kemampuan analisis lebih lanjut. Begitu pula dengan aspek kemandirian belajar mahasiswa belum tumbuh dengan optimal. Salah-satu indikator yang menunjukkan hal tersebut adalah ketika mahasiswa diminta untuk menjelaskan suatu konsep yang terdapat dalam buku ajar, mahasiswa masih mengalami kesulitan. Indikator lainnya adalah ketika mahasiswa mengerjakan tugas atau pekerjaan rumah, mahasiswa belum berusaha secara maksimal untuk mengatasi hal tersebut. Mahasiswa belum berusaha dengan cara mendiskusikannya dengan teman atau mencari referensi yang relevan. Ditinjau dari keterlibatan 
dalam kegiatan perkuliahan, mahasiswa secara umum masih pasif.

Terdapat beberapa faktor yang menyebabkan kondisi sebagaimana dikemukakan di atas, diantaranya adalah pelaksanaan pembelajaran yang kurang melibatkan mahasiswa secara aktif yang dapat melatih kemandirian belajar mahasiswa dan pemanfaatan sumber belajar yang belum optimal. Faktor lain yang menyebabkan belum tumbuhnya kemandirian belajar mahasiswa dimungkinkan juga oleh pelaksanaan Sistem Kredit Semester (SKS) belum optimal. Salah-satu penyebabnya adalah berkenaan dengan pemberian tugas terstruktur yang kurang terencana dengan baik, di samping belum adanya kontrol terhadap pelaksanaan tugas tersebut.

Mencermati hal-hal di atas, diperlukan perbaikan proses pembelajaran dengan cara mengimplementasikan pendekatan pembelajaran relevan yang dapat meningkatkan prestasi belajar dan dapat menumbuhkembangkan kemandirian belajar mahasiswa. Salah-satu pendekatan pembelajaran yang diharapkan dapat meningkatkan kemandirian belajar mahasiswa, dan kemampuan mahasiswa dalam mengkomunikasikan ide-idenya sekaligus dapat memanfaatkan sarana pendukung yang telah tersedia adalah pendekatan reciprocal teaching. Reciprocal teaching adalah suatu prosedur pengajaran atau pendekatan pengajaran yang dirancang untuk mengajarkan mahasiswa tentang strategi-strategi kognitif serta untuk membantu mahasiswa memahami materi perkuliahan dengan baik (Doolittle,et.al: 2006:106; Arends, 1997:266)

Doolittle (2006:107) dan Ann Brown (Arends, 1997:266) mengemukakan bahwa pada pendekatan reciprocal teaching diajarkan beberapa strategi pemahaman mandiri yang spesifik, seperti meringkas atau merangkum (summarizing) membuat pertanyaan (question generate), dan menjelaskan atau mempresentasikan (clarifying). Mahasiswa diberi tugas untuk mempelajari suatu topik atau konsep selanjutnya mahasiswa dituntut untuk dapat memahami pokok atau inti pada topik tersebut, memberikan contoh soal dan penyelesaiannya, kemudian mempertanggungjawabkan tugas tersebut dengan mempresentasikannya di kelas. Dengan demikian, mahasiswa telah dilatih untuk belajar secara mandiri dengan memanfaatkan sumber belajar yang tersedia.

Keterampilan-keterampilan yang dikembangkan melalui aktivitas pembelajaran dengan pendekatan reciprocal teaching akan lebih efektif dikuasai mahasiswa apabila diimplementasikan melalui aktivitas interaksi sosial antarmahasiswa. Memperhatikan hal tersebut, pendekatan lain yang relevan dikombinasikan dengan pendekatan reciprocal teaching adalah pendekatan cooperative learning.

Pembelajaran dengan pendekatan reciprocal teaching dan cooperative learning sejalan dengan prinsip pembelajaran konstruktivisme dengan pemahaman bahwa mahasiswa akan lebih mudah menemukan dan memahami konsep-konsep yang sulit apabila dapat saling mendiskusikan konsep-konsep tersebut dengan temannya (Lundgren, 1994; Slavin, 1995). Pembelajaran dengan pendekatan ini juga relevan dengan sistem SKS, mengingat mahasiswa diberi tugas secara mandiri untuk mempelajari suatu materi. Dengan demikian pendekatan ini juga diharapkan dapat mengoptimalkan implementasi sistem kredit semester.

\section{METODE}

Penelitian ini merupakan penelitian tindakan kelas terdiri atas dua siklus. Penelitian ini dilaksanakan di Jurusan Pendidikan Kimia FMIPA UNY Yogyakarta, selama bulan Februari-Juli 2010. Subjek penelitian ini adalah mahasiswa Program Studi Pendidikan Kimia Kelas yang sedang menempuh semester genap pada tahun akademik 2009/2010. Target subjek penelitian ini berjumlah 39 mahasiswa. Prosedur penelitian yang dilakukan mengacu pada rancangan penelitian yang dikemukakan oleh Kemmis dan Mc.Taggart (Sukmadinata, 2006; Kunandar, 2008) terdiri atas tiga tahap, yaitu tahap perencanaan, tahap pelaksanaan (tindakan dan observasi), dan tahap refleksi.

Penelitian Tindakan kelas yang dilakukan terdiri atas dua siklus, siklus pertama dilakukan dalam tujuh kali pertemuan, sedang siklus 
kedua enam kali (semuanya 13 kali pertemuan). Untuk memperoleh data penelitian digunakan dua perangkat pembelajaran, yaitu rencana perkuliahan dan buku ajar. Instrumen penelitian yang digunakan terdiri atas lembar observasi kegiatan pembelajaran, lembar penilaian presentasi mahasiswa, angket kemandirian belajar mahasiswa, angket tanggapan mahasiswa, dan tes prestasi belajar.

Data yang diperoleh dianalisis secara kuantitatif dan kualitatif. Teknik kualitatif digunakan untuk menentukan keterlaksanaan rencana perkuliahan dan rencana tindakan, mendeskripsikan aktivitas mahasiswa dan dosen dalam kegiatan pembelajaran, kemampuan mahasiswa berdiskusi dan mempresentasikan tugas, serta hambatan-hambatan yang muncul dalam pelaksanaan pembelajaran. Teknik kuantitatif digunakan untuk mendeskripsikan prestasi belajar mahasiswa, tanggapan mahasiswa terhadap kegiatan pembelajaran, dan untuk mengetahui apakah implementasi pembelajaran dapat meningkatkan kemandirian belajar mahasiswa.

Untuk mendeskripsikan implementasi pendekatan reciprocal teaching dan cooperative learning akan ditinjau dari aspek aktivitas dosen dalam melaksanakan kegiatan pembelajaran, aktivitas mahasiswa dalam mengikuti kegiatan pembelajaran, partisipasi mahasiswa dalam kegiatan pembelajaran, kendala-kendala yang dihadapi dalam mengimplementasikan pendekatan reciprocal teaching dan cooperative learning, dan aspek-aspek spesifik lainnya.

Untuk mendeskripsikan prestasi belajar mahasiswa akan ditinjau dari ketuntasan belajarnya. Seorang mahasiswa dikatakan tuntas belajar jika memperoleh nilai lebih dari atau sama dengan $\mathrm{C}+$ (atau skor 64 dalam rentang penilaian 0 - 100). Selanjutnya suatu kelas dikatakan tuntas secara klasikal, jika terdapat paling sedikit $75 \%$ mahasiswa telah tuntas belajar secara individual.

Untuk mendeskripsikan kemampuan presentasi mahasiswa digunakan hasil observasi kemampuan presentasi mahasiswa dengan menggunakan lembar observasi kemampuan presentasi mahasiswa. Penilaian kemampuan presentasi mahasiswa tidak dilakukan secara individual, melainkan terhadap kelompok. Kriteria penilaian kemampuan presentasi mahasiswa (KPM) adalah sebagai berikut:

$1,0 \leq \mathrm{KPM}<2,0$ : Kurang memuaskan

2,0 $\leq \mathrm{KPM}<3,0$ : Cukup memuaskan

$3,0 \leq \mathrm{KPM}<3,5$ : Memuaskan (Baik)

$3,5 \leq \mathrm{KPM}<4,0$ : Sangat memuaskan

Untuk mendeskripsikan tanggapan mahasiswa terhadap kegiatan pembelajaran dan kemandirian belajar mahasiswa setelah mengikuti kegiatan pembelajaran, digunakan hasil angket yang diberikan kepada mahasiswa setelah berakhirnya kegiatan perkuliahan. Hasil kedua angket tersebut dianalisis dengan cara sebagai berikut. Mahasiswa dikatakan telah memiliki kemandirian belajar yang baik bila jumlah ratarata persentase mahasiswa yang memilih kategori Selalu dan Sering lebih besar daripada jumlah rata-rata persentase mahasiswa yang memilih kategori Jarang, Tidak Pernah, dan Tidak berpendapat. Selanjutnya mahasiswa dikatakan mempunyai tanggapan positif terhadap kegiatan pembelajaran bila jumlah rata-rata persentase mahasiswa yang memilih kategori Setuju dan Sangat Setuju lebih besar daripada jumlah rata-rata persentase mahasiswa yang memilih kategori Ragu-ragu, Tidak Setuju, dan Sangat Tidak Setuju.

\section{HASIL DAN PEMBAHASAN \\ Hasil Belajar Mahasiswa pada Perkuliahan Kimia Fisika II}

Nilai akhir mahasiswa ditentukan berdasarkan kesepakatan dengan mahasiswa pada awal perkuliahan, yaitu ditentukan berdasarkan nilai tugas dan presensi, nilai ujian sisipan selama 2 kali, dan nilai ujian akhir semester. Hasil ujian sisipan I (Siklus I) terdapat 10 mahasiswa dari 39 mahasiswa $(25,64 \%)$ yang mendapatkan nilai 64 ke atas. Selanjutnya pada siklus II telah dilaksanakan ujian sisipan II dan Ujian akhir Semester dengan hasil: pada ujian sisipan II sebanyak 28 dari 39 mahasiswa $(71,80 \%)$ mendapatkan nilai 64 ke atas dan pada ujian akhir semester sebanyak 21 mahasiswa dari 39 mahasiswa mendapatkan nilai 64 ke atas $(53,85 \%)$. 
Dengan demikian, dapat dikatakan bahwa berdasarkan nilai murni hasil ujian sisipan dan ujian akhir semester baik pada siklus I maupun pada siklus II belum tercapai ketuntasan belajar secara klasikal. Namun demikian, apabila dilihat dari nilai rata-rata ujian sisipan menunjukkan kenaikan dari 54,38 menjadi 75,64. Begitu pula dengan nilai minimal dan nilai maksimal mahasiswa mengalami peningkatan dari siklus I ke siklus II. Kemudian dilihat dari standar deviasinya mengalami penurunan pada siklus II, hal tersebut menunjukkan kemampuan mahasiswa semakin seragam. Secara sederhana dapat dikatakan bahwa kemampuan mahasiswa relatif meningkat. Hal ini dapat disebabkan adanya aktivitas individu dan kelompok yang dilakukan oleh mahasiswa dalam memahami materi yang ditugaskan di samping bimbingan yang diberikan dosen.

Tabel 1 menunjukkan daftar nilai Kimia Fisika II, sebanyak 36 mahasiswa dari 39 mahasiswa $(92,31 \%)$ telah mengalami ketuntasan belajar secara individual. Seorang mahasiswa dikatakan telah tuntas belajar secara individual apabila ia memperoleh nilai paling sedikit 64 atau paling rendah $\mathrm{C}+$. Dengan mengacu pada kriteria ketuntasan belajar secara klasikal yang telah ditentukan, yaitu ketuntasan belajar secara klasikal dapat dicapai apabila terdapat paling sedikit $75 \%$ mahasiswa telah mengalami ketuntasan belajar secara individual.

Dengan demikian, dapat disimpulkan bahwa secara klasikal mahasiswa telah mengalami ketuntasan belajar. Hal ini ditunjukkan oleh persentase mahasiswa yang tuntas belajarnya secara individual sebanyak $92,31 \%$.

Ketuntasan belajar yang telah dicapai dapat disebabkan oleh aktivitas mahasiswa dalam mengerjakan tugas atau materi yang harus dipahaminya melalui kegiatan di luar kelas sebelum pembelajaran dengan cara mencari referensi lain, berdiskusi dengan teman, konsultasi dengan dosen di luar jam perkuliah- an, serta adanya tuntutan untuk mengulang materi perkuliahan (Hamra and Syatriana, 2012:1). Tentu saja, hal tersebut sangat positif, sehingga di samping memberikan pesan eksplisit kepada mahasiswa untuk mengerjakan tugas seperti merangkum, membuat pertanyaan, dan mempresentasikan tugasnya. Pembelajaran yang dikembangkan juga memberikan pesan implisit. Hal tersebut sesuai dengan yang dikemukakan oleh Denton (2012:37).

Pesan implisit yang dimaksud berkenaan dengan proses yang dilakukan oleh mahasiswa dalam mengerjakan dan mempresentasikan tugasnya dengan mempertahankan pemahaman konsep di hadapan mahasiswa lain. Hal tersebut sesuai dengan yang dikemukakan oleh Patahudin dan Siti Maesuri (1998) bahwa dalam memberikan tugas kepada mahasiswa, yang dipentingkan bukan hanya tujuan eksplisit melainkan juga pesan implisit. Pesan implisit tersebut meliputi perilaku yang diharapkan dimiliki oleh mahasiswa dan syarat yang harus dikerjakan mahasiswa agar dapat mengerjakan tugas dengan baik (Haley-Mize dan Reeves, 2013:75). Dengan demikian, pesan implisit dalam pendekatan reciprocal teaching dan cooperative learning adalah pada saat mahasiswa mengerjakan tugas, mahasiswa dituntut berdiskusi, saling bertukar pikiran, bertanya pada dosen di luar jam perkuliahan dan masingmasing berusaha semaksimal mungkin agar kelompoknya berhasil (Bostwick et al, 2013).

Mencermati proses yang dilakukan oleh mahasiswa dalam melaksanakan tugas, dapat dilihat bahwa mahasiswa secara aktif berusaha memahami materi perkuliahan. Mahasiswa berusaha mengkonstruksi pengetahuan mereka dengan cara membaca bahan ajar, referensi lain, berdiskusi dengan teman, atau bertanya kepada dosen (Denton, 2012:35). Hal tersebut secara tidak langsung akan meningkatkan pemahaman mahasiswa terhadap materi perkuliahan. 
Tabel 1. Deskripsi Nilai Kimia Fisika II Mahasiswa

\begin{tabular}{|c|c|c|c|c|c|c|c|}
\hline Nilai & A- & $\mathrm{B}+$ & B & B- & $\mathrm{C}+$ & $\mathrm{C}$ & $\mathrm{D}$ \\
\hline Jumlahmaha-3 (7,69\%) & $13(33,33)$ & $10(25,64 \%)$ & $6(15,39 \%)$ & $4(10,26 \%)$ & $0(0 \%)$ & $3(7,69 \%)$ & $0(0 \%)$ \\
\hline siswa $\quad 41,02 \%$ & & $51,29 \%$ & & & $7,69 \%$ & & $0 \%$ \\
\hline
\end{tabular}

Tabel 2. Kemampuan Presentasi Mahasiswa

\begin{tabular}{lcc}
\hline & $\begin{array}{c}\text { Kemampuan Presentasi } \\
\text { Mahasiswa (KPM) }\end{array}$ & Kategori KPM \\
\hline Rerata skor kelompok siklus I & 2,03 & Cukup Memuaskan \\
Rerata skor kelompok siklus II & 2,57 & Cukup Memuaskan \\
Rerata skor total KPM & 2,30 & Cukup Memuaskan \\
\hline
\end{tabular}

Tabel 3. Deskripsi Kemandirian Belajar Mahasiswa

\begin{tabular}{lcc}
\hline Persentase Mahasiswa yang & Kemandirian Belajar (\%) \\
Memberikan Tanggapan & & Persentase $(\%)$ \\
\hline Selalu & 11,14 & 51,43 \\
Sering & 40,29 & \\
Jarang & 38,43 & 48,71 \\
Tidak pernah & 6,86 & \\
Tidak berpendapat & 3,43 & \\
\hline
\end{tabular}

Tabel 4. Tanggapan Mahasiswa terhadap Kegiatan Pembelajaran

\begin{tabular}{lcc}
\hline Rata-rata persentase mahasiswa & Tanggapan Mahasiswa (\%) & Persentase (\%) \\
yang memilih kategori & & \\
\hline Sangat setuju & 6,79 & 67,14 \\
Setuju & 60,36 & 32,86 \\
Tidak setuju & 24,11 & \\
Sangat tidak setuju & 0,71 & \\
Tidak berpendapat & 8,04 & \\
\hline
\end{tabular}

\section{Kemampuan Presentasi Mahasiswa}

Tabel 2 menunjukkan deskripsi kemampuan presentasi mahasiswa (KPM) untuk masing-masing siklus pembelajaran yang dilaksanakan. Terdapat 11 aspek yang dinilai untuk mengetahui kemampuan prsentasi mahasiswa. Berdasarkan Tabel 2, dapat dilihat bahwa ratarata kemampuan presentasi mahasiswa pada siklus pertama dan kedua berturut-turut adalah 2,03 dan 2,57. Dengan demikian kemampuan presentasi mahasiswa telah mengalami peningkatan. Peningkatan kemampuan mahasiswa dalam presentasi dapat dimengerti karena seiring berjalannya waktu, mahasiswa banyak belajar bagaimana cara mempresentasikan tugasnya dengan baik. Mahasiswa dapat belajar dari kelompok lain yang telah presentasi dan tentu saja juga belajar dari komentar-komentar serta bimbingan dosen terhadap presentasi kelompok (Hsiung, 2012:134).

Perbaikan kemampuan presentasi mahasiswa juga dapat disebabkan oleh adanya bimbingan yang relatif memadai dari dosen sebelum suatu kelompok mempresentasikan tugasnya. Namun demikian, kemampuan presentasi mahasiswa (KPM) secara keseluruhan adalah 2,30. Berdasarkan kriteria yang telah ditentukan, kemampuan presentasi mahasiswa termasuk kategori cukup memuaskan (cukup baik). Hal tersebut dapat disebabkan oleh adanya beberapa kelompok yang tidak memanfaatkan konsultasi dengan dosen di luar jam perkuliahan untuk menanyakan konsep yang sulit dipahami sebelum melakukan presentasi sehingga pada saat presentasi berlangsung terdapat beberapa kelompok yang masih salah konsep 
dan tidak dapat menjawab pertanyaan mahasiswa lain dengan baik.

\section{Kemandirian Belajar Mahasiswa}

Berdasarkan Tabel 3, jumlah persentase mahasiswa yang memilih kategori selalu dan sering sebesar $51,43 \%$ lebih besar daripada mahasiswa yang memilih kategori jarang, tidak pernah, dan tidak berpendapat, yaitu $48,71 \%$. Dengan demikian dapat disimpulkan bahwa mahasiswa memiliki kemandirian belajar yang baik. Namun karena perbedaannya hanya sekitar 2,72\%, sehingga antara mahasiswa yang mandiri dalam belajarnya dengan yang belum hampir sama jumlahnya.

Tumbuhnya kemandirian belajar mahasiswa diwujudkan dalam bentuk meningkatnya keyakinan diri mahasiswa, menentukan strategi belajar secara mandiri, meningkatnya aktivitas mahasiswa dalam kegiatan pembelajaran, dan tumbuh motivasi yang baik pada diri mahasiswa (Sumarmo, 2004; Mynard, 2002). Indikator tumbuhnya keyakinan diri mahasiswa terlihat dari hasil angket bahwa sebagian besar mahasiswa mengaku jika megalami kesulitan, mereka berusaha menyelesaikannya dengan cara mencari referensi, berdiskusi dengan teman, atau bertanya pada dosen, yakin dapat mengikuti kegiatan perkuliahan dengan baik, yakin dapat memperoleh nilai yang baik dalam perkuliahan, yakin dapat menyelesaikan masalah atau soal dengan baik, dan mengetahui kelebihan dan kekurangan mereka. Ditinjau dari aktivitas mahasiswa dalam mengikuti kegiatan perkuliahan, sebagian besar mahasiswa mengaku dapat mengikuti kegiatan pembelajaran dengan baik.

Terdapat hal yang perlu mendapatkan perhatian, yakni sekitar 50\% mahasiswa mengaku jarang menetapkan tujuan dan strategi belajar, jarang mengevaluasi strategi, jarang membuat jadwal belajar dan menepatinya, jarang mempelajari terlebih dahulu materi yang akan dikuliahkan, jarang mempelajari dan mengulang kembali materi, jarang mengerjakan soalsoal latihan yang bukan tugas perkuliahan Kimia Fisika II, dan jarang memanfaatkan waktu luang untuk mempelajari materi perkuliahan. Dengan demikian, masih banyak mahasiswa yang belum memiliki kemandirian belajar. Hal tersebut dimungkinkan karena mereka kurang terbiasa dan perlu ditingkatkan lagi kemandirian belajarnya.

\section{Tanggapan Mahasiswa terhadap Kegiatan Pembelajaran}

Hasil tanggapan mahasiswa ditunjukkan pada Tabel 4. Jumlah persentase mahasiswa yang memilih kategori sangat setuju dan setuju sebesar $67,14 \%$ lebih besar daripada mahasiswa yang memilih kategori tidak setuju, sangat tidak setuju, dan tidak berpendapat, yaitu 32,86\%. Dengan demikian, dapat disimpulkan bahwa mahasiswa memberikan tanggapan positif terhadap kegiatan perkuliahan Kimia Fisika II.

Minat yang tumbuh pada diri mahasiswa dimanifestasikan dengan cara aktif dalam mengikuti pembelajaran. Aktivitas yang dimaksud meliputi aktivitas dalam mempresentasikan tugas, berdiskusi, bertanya, dan mencari referensi lain selain buku ajar. Berdasarkan pengamatan peneliti, pada tahap awal perkuliahan, hanya beberapa mahasiswa yang terlibat aktif dalam diskusi atau tanya jawab.

Namun, pada pertemuan berikutnya, mahasiswa semakin antusias bertanya kepada kelompok yang sedang mempresentasikan tugasnya. Antusiasme tersebut sesuai dengan hasil angket, yaitu $65,71 \%$ mahasiswa berminat mengikuti kegiatan perkuliahan dan 57,14\% mahasiswa berani mengemukakan pendapat, 97,15\% mahasiswa bersedia menerima pendapat teman dalam diskusi, $97,14 \%$ mahasiswa mengungkapkan setuju untuk peduli terhadap kesulitan teman ketika berdiskusi, dan 97,14\% mahasiswa bersedia berbagi tugas dalam menyelesaikan tugas dalam kegiatan diskusi. Sebanyak $57,14 \%$ mahasiswa yakin dapat memahami materi perkuliahan dan 82,86\% mahasiswa yakin bahwa Kimia Fisika II bermanfaat dan mereka mengetahui manfaat dari perkuliahan Kimia Fisika II tersebut.

Hal tersebut sesuai dengan yang dikemukakan oleh Slameto (1995) bahwa minat dimanifestasikan melalui partisipasi dalam 
suatu aktivitas dan cenderung memberikan perhatian yang lebih besar terhadap objek tersebut. Mencermati proses yang dilakukan oleh mahasiswa dalam melaksanakan tugas tersebut, dapat diperhatikan bahwa mahasiswa secara aktif berusaha memahami materi perkuliahan.

Mahasiswa tidak tergantung pada penjelasan dosen di kelas. Sebanyak 91,43\% mahasiswa mengaku bila mengalami kesulitan dalam mempelajari Kimia Fisika II, mereka mendiskusikannya dengan teman atau membaca buku lain yang sesuai dan sebanyak $54,29 \%$ mahasiswa mengaku bahwa suasana kegiatan perkuliahan dapat membantu mereka memahami materi kuliah.

Hal tersebut juga sesuai dengan paham konstruktivisme (Denton, 2012; Suparno, 1997; Nur, 1995) bahwa pengetahuan tidak dapat dipindahkan begitu saja dari dosen kepada mahasiswa. Proses ini secara tidak langsung akan meningkatkan pemahaman mahasiswa terhadap materi perkuliahan. Namun demikian, implementasi pendekatan reciprocal teaching dan cooperative learning memiliki beberapa kelemahan. Kelemahan yang dimaksud antara lain memerlukan waktu relatif lama, terlebih apabila kelompok yang mendapat giliran untuk presentasi belum menguasai materi dengan baik. Hal tersebut menuntut dosen untuk mengoreksi, memperjelas, atau bahkan mengulangi penjelasan mahasiswa. Keadaan tersebut dilakukan juga dalam penelitian ini.

Pada pertemuan lain, dosen mengulas kembali materi yang disampaikan mahasiswa dan memberikan latihan soal. Lamanya waktu yang diperlukan akan berakibat tidak terselesaikannya materi perkuliahan yang relatif banyak. Hal tersebut dapat diatasi dengan memilih beberapa topik yang akan ditugaskan kepada mahasiswa untuk dipresentasikan. Di samping mempertimbangkan tingkat kesulitan materi. Terbatasnya waktu pertemuan juga tidak memungkinkan semua mahasiswa mendapatkan giliran untuk mempresentasikan tugas, Namun, hal tersebut dapat diatasi dengan melakukan penunjukkan atau dengan cara diundi terhadap kelompok mahasiswa yang akan melakukan presentasi. Hal tersebut tentu saja diharapkan agar semua kelompok atau mahasiswa senantiasa mempersiapkan diri.

Terlalu seringnya pemberian tugas memungkinkan mahasiswa akan merasa bosan, apalagi materi yang ditugaskan relatif sulit bagi mahasiswa. Oleh karena itu, perlu dipertimbangkan pemilihan materi yang akan ditugaskan kepada mahasiswa, yaitu materi yang tidak terlalu sulit. Hal lain yang dapat diamati adalah seringnya presentasi yang dilakukan mahasiswa, kesempatan untuk berlatih soal cenderung berkurang sehingga kemampuan pemecahan masalah yang lebih kompleks cenderung akan berkurang. Pada tipe-tipe soal yang tidak terlalu sulit, mahasiswa cenderung dapat mengerjakan dengan baik. Setidaknya hal tersebut terlihat pada ujian sisipan I dan II serta ujian akhir. Tentu saja hal tersebut perlu dipertimbangkan mengenai frekuensi pembelajaran dengan pendekatan reciprocal teaching dan cooperative learning, sehingga untuk berlatih soal dapat tersedia waktu yang cukup. Hal lain yang dipandang kurang mendukung implementasi pendekatan reciprocal teaching dan cooperative learning dalam perkuliahan Kimia Fisika II adalah minimnya referensi relevan di perpustakaan.

\section{PENUTUP}

Berdasarkan hasil penelitian dan mengacu pada masalah yang diajukan dapat dikemukakan kesimpulan bahwa setelah mengikuti perkuliahan dengan pendekatan reciprocal teaching dan cooperative learning, terdapat 92,31\% mahasiswa prodi Pendidikan Kimia semester genap tahun akademik 2009/2010 yang telah tuntas belajarnya secara individual pada matakuliah Kimia Fisika II. Atas dasar ketuntasan belajar mahasiswa secara individual lebih dari $75 \%$, maka secara klasikal mahasiswa tersebut sudah tuntas belajarnya. Kemandirian belajar mahasiswa prodi Pendidikan Kimia semester genap tahun akademik 2009/2010 setelah mengikuti perkuliahan dengan pendekatan reciprocal teaching dan cooperative learning termasuk kategori baik. Implementasi pendekatan reciprocal teaching dan cooperative learning berjalan dengan baik. Mahasiswa me- 
nunjukkan tanggapan positif terhadap kegiatan pembelajaran. Mahasiswa terlihat antusias dan terlibat aktif dalam mengikuti pembelajaran. Kemampuan presentasi mahasiswa dikategorikan cukup dan meningkat dari siklus I ke siklus II.

Berdasarkan hasil penelitian yang diperoleh, peneliti menyarankan hasil penelitian dapat dimanfaatkan sebagai pertimbangan bagi para dosen dalam melakukan pembelajaran. Dengan menerapkan pendekatan reciprocal teaching dan cooperative learning, pembelajaran akan lebih bervariasi. Aktivitas mahasiswa dan juga minat mahasiswa akan meningkat. Dengan demikian sebaiknya pendekatan reciprocal teaching dan cooperative learning diterapkan dalam perkuliahan mata kuliah lain, meskipun hanya sebagai variasi atau pelengkap saja. Untuk lebih mengoptimalkan implementasi pendekatan ini dalam kegiatan perkuliahan perlu didukung referensi yang memadai serta perlu adanya pengelolaan waktu secara optimal.

\section{UCAPAN TERIMA KASIH}

Penelitian ini dilaksanakan atas bantuan dana Program Hibah Kompetisi Institusi tahun anggaran 2010/2011 nomor kontrak: 06/KTG-PHKI/III/2010. Untuk itu, penulis mengucapkan terimakasih kepada pemberi dana.

\section{DAFTAR PUSTAKA}

Arends, Richard I. 1997. Classroom Instruction and Management. New York: Mc. GrawHill.

Bostwick, D., J. Foster, A. Bloomfield, and P. Rutledge. 2013. "Clicking Your Way to Student Success", dalam Techniques, 88 (1), $28-31$.

Denton, D.W. 2012. "Enhancing Instruction through Constructivism, Cooperative learning, and Cloud Computing", dalam TechTrends, 56 (4), 34-41.

Doolittle, E. P., D. Hicks, C. F. Triplett, and W. D. Nichols. 2006. "Reciprocal Teaching for Reading Comprehension in Higher Education: A Strategy for Fostering the Deeper Understanding of Texts", dalam International Journal of Teaching and Learning in Higher Education, 17 (2), 106-118.

Haley-Mize, Shannon and R. Stacy. 2013. "Universal Design for Learning and Emergent-literacy Development; Instructional Practices for Young Learners", dalam Delta Kappa Gamma Bulletin, 79 (2), 70-78.

Hamra, A. and E. Syatriana. 2012. "A Model of Reading Teaching for University EFL Students; Need Analysis and Model Design", dalam English Language Teaching, 5(10), $1-11$.

Hsiung, Chin Min. 2012. "The Effectiveness of Cooperative Learning", dalam Journal of Engineering Education, 101(1), 119-137.

Kunandar. 2008. Penelitian Tindakan Kelas sebagai Pengembangan Profesi Guru. Jakarta:PT Rajagrafindo Persada.

Lundgren, Linda. 1994. Cooperative Learning in the Science Classroom. Ohio: Glencoe.

Mynard, Jo and Sorflaten. 2002. Independent Learning in Your Classroom. www.e-psikologi.com. Diunduh 2 Maret 2010.

Nur, Muhammad. 1995. Pendekatan-pendekatan Konstruktivis dalam Pembelajaran Kooperatif. Surabaya : IKIP Surabaya.

Patahudin, Siti Maesuri. 1998. Metode Pemberian Tugas Menulis Terfokus dalam Proses Pembelajaran Matematika Siswa Kelas II SMU Khadijah Surabaya. Tesis. Pascasarjana IKIP Surabaya.

Slameto. 1995. Belajar dan Faktor-Faktor yang Mempengaruhinya. Jakarta: Rineka Cipta 
Slavin, Robert E. 1995. Cooperative Learning:

Theory and Practice. Boston : Allyn and Bacon Publisher.

Sukmadinata, Nana Syaodih. 2006. Metode Penelitian Pendidikan. Bandung:PT Remaja Rosdakarya.

Sumarmo, Utari. 2004. "Kemandirian Belajar: Apa, Mengapa, dan Bagaimana Dikembangkan pada Peserta Didik?". Makalah Lokakarya. Jurdik Matematika FMIPA UNY.
Suparno, Paul. 1997. Filsafat Konstruktivisme dalam Pendidikan. Yogyakarta:Kanisius.

Riyanto, Yatim. 2010. Paradigma Baru Pembelajaran: Sebagai Referensi bagi Pendidik dalam Implementasi Pembelajaran yang Efektif dan Berkualitas. Jakarta: Kencana Prenada Media Group. 